\title{
O SILÊNCIO DE FILEBO
}

\author{
LE SILENCE DE PHILEBUS
}

Rafael Leopoldo*

\section{RESUMO}

O presente artigo é uma reflexão sobre o diálogo Filebo, de Platão. Nossa temática, a propósito dessa obra, é a função do silêncio de Filebo. Para esta análise, percorremos dois filósofos: o francês Michel Onfray, na Contra-história da filosofia, e o alemão Hans-Georg Gadamer em A ideia do bem entre Platão e Aristóteles. Em cada um desses filósofos, vamos ter uma compreensão diferente do diálogo de Platão e, portanto, da questão do silêncio do personagem principal. Nessa ponderação, Michel Onfray apresenta toda sua aliança com o pensamento de Friedrich Nietzsche. Hans-Georg Gadamer, por sua vez, apresenta sua afinidade teórica com o pensamento de Martin Heidegger. Dessa forma, o silêncio pode ser compreendido tanto como uma positivação de um hedonismo (a visão de Onfray-Nietzsche) quanto um rechaço à positivação do saber hermenêutico (Gadamer-Heidegger). Por último, nós abordamos uma terceira possibilidade interpretativa que é a da impossibilidade de se viver ao modo filosófico.

PALAVRAS-CHAVE: Filebo. Diálogo. Democracia. Silêncio.

\section{RÉSUMÉ}

Cet article est une réflexion sur le dialogue Philebus de Platon. Notre thème, à propos de cet ouvrage, est celui de la fonction du silence de son personnage principal. Pour l'analyser, nous parcourons deux philosophes: le français Michel Onfray dans son livre Contre-histoire de la philosophie, et l'allemand Hans-Gerog Gadamer enL'Idée du bien comme enjeu platonicoaristotélicien. Chez chacun de ces philosophes, nous aurons une compréhension différente du dialogue de Platon et, par conséquent, de la question du silence du personnage principal. Dans cette considération, Michel Onfray présente toute son alliance avec la pensée de Friedrich Nietzsche. Hans-Georg Gadamer, à son tour, montre son affinité théorique avec la pensée de Martin Heidegger. De cette manière, le silence peut être aussi compris comme une positivation d'un hédonisme (la vision d'Onfray-Nietzsche) que comme un rejet de la positivation du savoir herméneutique (Gadamer-Heidegger). Enfin, nous apportons une troisième possibilité d'interprétation du mutisme de Philebus qui consiste à comprendre l'impossibilité du mode de vie philosophique.

MOTS-CLES: Philebus. Dialogue. Démocratie. Silence

\section{O FILEBO DE MICHEL ONFRAY}

O filósofo francês Michel Onfray na sua Contra-história da filosofia: a sabedoria dos antigos propõe outra historiografia da filosofia. Onfray constata que a história da filosofia é

\footnotetext{
* Mestre em psicologia pela Universidade Federal de Juiz de Fora (UFJF). Mestrando em Filosofia pela FAJE, graduado em filosofia pela PUC Minas. E-mail: ralasfer@gmail.com.
} 
platônica, cristã e alemã. Portanto, o filósofo francês procura outras paisagens filosóficas que fogem da tradição, procura o que chamou de uma contra-história da filosofia. Se Platão, o idealismo e a metafísica fazem parte da história dos vencedores, seria tempo de escrever uma história dos vencidos. Diante dessas questões Onfray (2008, p. 32) escreve que:

\begin{abstract}
A história da filosofia, tal como aparece nas enciclopédias e nos manuais, tal como é ensinada e estudada na Universidade, tal como é editada, difundida e promovida, confunde-se com a dos vencedores. Não há piedade para com os vencidos, que são desprezados, esquecidos, negligenciados: pior, são depreciados por meio da caricatura. (...) Assim como os ganhadores não podem dizer serenamente a verdade dos perdedores, os vencidos não podem escrever serenamente sua história.
\end{abstract}

Onfray, pensando na história dos vencidos, tenta reescrever a história de uma filosofia mais jubilosa, assim ele confessa os seus pressupostos propondo: "uma filosofia que não se constitui contra o corpo, a despeito dele ou sem ele, mas com ele" (ONFRAY, 2008, p. 22). Para Onfray essa filosofia com o corpo é, igualmente, uma filosofia hedonista. A história da filosofia que Onfray aponta é, portanto, a que prefere esculpir o corpo e as paixões contra aquelas que prefeririam destruí-los. A história da filosofia de Onfray então se configura como: hedonista, materialista, sensualista, existencial, utilitarista, pragmática, ateia, corporal e encarnada.

Enfatizar esses dados da construção da filosofia de Onfray é importante para a compreensão da análise que ele faz do Filebo. A leitura de Onfray, da história da filosofia e, ademais, do Filebo está envolta na leitura que Friedrich Nietzsche faz de Platão e da filosofia. Assim, Platão não é tão somente grego, mas, também, diante de um espelho anacrônico ele é a encarnação do próprio cristianismo e da filosofia alemã, ou seja, de toda a história dos vencedores. Daí, compreendemos o motivo do Filebo ser um diálogo importante para Onfray, pois lembremos que o subtítulo desse diálogo é "sobre o prazer". O prazer, para Onfray, remete ao corpo, ao hedonismo; remete, especialmente, ao que foi negado pela tradição filosófica. Dessa maneira, o personagem Filebo em Platão surge como um personagem conceitual do hedonismo. Todavia, esse personagem conceitual aparece como uma caricatura. Onfray (2008, p.152, grifos do autor) recorda que: "vencendo sem perigo triunfamos sem glória”.

Diante da leitura que Onfray faz de Filebo o nosso intuito será primeiro a apreensão da sua crítica em geral e, depois, o entendimento que o filósofo francês tem do silêncio de Filebo. Trata-se de refletir como ele analisa a não participação do personagem Filebo no 
desenvolvimento do diálogo platônico. A respeito do primeiro ponto, Onfray, enfatiza dois elementos a respeito de Platão: 1) o filósofo grego escreveria como num palco, como num teatro; 2) e pensaria como um lutador. O primeiro ponto reverbera a própria forma dos diálogos platônicos, e o segundo num relato em que Diógenes de Laércio afirma que Platão teria participado de uma competição de luta. Onfray (2008, p. 143) sustenta que "sua formação inicial de lutador e seu tropismo pelo teatro não o deixam durante o seu tempo de magistério na Academia".

Com esses dois elementos postos, podemos agora compreender como eles afetariam na própria produção do Filebo, ou seja, como os personagens dos diálogos platônicos são construídos para Onfray (2008, p. 144):

\begin{abstract}
Platão pensa como esportista fascinado pelo modo agônico e redige como polemista mau jogador animado pela preocupação de ganhar lutas tanto mais fáceis porque ele arranja adversários muito aquém de sua medida para vencê-los facilmente, compreendemos as precauções que devemos observar quando nos indagamos sobre os interlocutores de Sócrates, seu eterno testa-de-ferro, seu escravo conceitual para sempre. Filebo e Protarco, que lhe servem de saco de pancada com o qual ele se entusiasma desenfreadamente, têm muito pouca relação com filósofos hedonistas dignos desse nome.
\end{abstract}

Platão como teatrólogo estaria fascinado pelo modo agônico e polemista, mas o Platão boxeador estaria fascinado por vencer as lutais fáceis; assim, tem-se o próprio assassinato da visão hedonista, pois o que Platão ataca é, principalmente, uma caricatura, ele lutaria contra um bode expiatório.

Se Platão monta um cenário totalmente anti-hedonista, e no ringue a sua luta é contra personagens conceituais anêmicos, a proposta de Onfray parece ser a de revigorar o próprio hedonismo. O filósofo francês, diante dessa tentativa, afirma que:

Contrário a uma oposição que implica a escolha entre duas impossibilidades (uma vida de prazer sem reflexão, uma vida de reflexão sem prazer), um hedonista digno desse nome, um verdadeiro adversário de Platão, numa cena filosófica real e não truncada, recusaria o maniqueísmo, descartaria o dualismo redutor e reivindicaria para si essa opção de uma terceira via. Não deixaria sua ideia ser roubada vendo escapulir o astuto, trocista e fanfarrão: travaria discussões sobre as partes respectivas a serem deixadas ao prazer numa vida de reflexão e vice-versa; dissertaria sobre os prazeres que impedem a reflexão, os que nascem da conversação, da pesquisa e do trabalho da inteligência; não oporia, como Sócrates, os prazeres bons, relacionados à alma, ao infinito, ao ilimitado, aos prazeres maus, associados ao corpo, ao finito, ao limitado; impediria a remissão sistemática do hedonismo aos galinheiros e estábulos [...] (ONFRAY, 2008, p. 151). 
Para Onfray as teses hedonistas são reduzidas a personagens ridículos, não haveria o reconhecimento dos seus interlocutores. Assim, a luta é falseada e ganha de antemão: “o lutador [Platão] escolhe seus adversários entre os fracotes” (ONFRAY, 2008, p. 152). Logo, cabe-nos, também, pensar sobre os personagens que ele chama de "fracotes". Trata-se, então, de refletirmos sobre Protarco e, sobretudo, Filebo.

Onfray propõe duas etimologias para os nomes dos personagens de Platão. Filebo designa aquele que gosta de jovens e Protarco aquele que governa. No caso de Protarco, Onfray caracteriza-o da seguinte maneira:

Protarco desempenha do início ao fim o papel do tolo. Suas intervenções pesam uma
dezena de linhas em um diálogo de cento e cinquenta páginas. E suas intervenções
brilham por um ridículo consumado: não compreende, pede para repetir, repete por
sua vez, pergunta para ter certeza de que compreendeu, deixa perguntas sem
resposta, responde ao mesmo tempo, ou tarda demais. Quando toma a palavra,
aquiesce, consente, valida, diz estar de acordo: claro, com certeza, evidentemente -
seu registro não vai além do assentimento beato. Se o hedonismo se configura em
tais inutilidades, não há dúvida de que se aspire a seu contrário [...] (ONFRAY,
2008, p. 145-146).

Protarco não figuraria um bom lutador diante de Platão, aliás, ele não encarnaria a tese hedonista, mas, sim, a caricatura de fácil abate. Onfray chama Protarco de: "Beato, tolo, bobo e silencioso, Protarco deve também compor com a defesa - virtual! - de uma tese redutora e caricatural. Ele encarna o imperativo categórico hedonista: o prazer identifica-se com o bem. De modo que ele depõe a favor da vida feliz." (ONFRAY, 2008, p. 146, grifo nosso).

Assim sendo, é importante notar que Onfray adjetiva o próprio Protarco de "silencioso". Não obstante, o silêncio de Protarco ainda é diferente do silêncio de Filebo. O silêncio de Protarco, na leitura de Onfray, parece ser o silêncio do tolo que tudo aceita, o silêncio daquele que tão somente concorda com o jogo verbal socrático platônico. Porém, Protarco está dentro do diálogo mesmo que seja como o tolo. O silêncio de Filebo, por sua vez, estaria numa outra esfera. Onfray propõe duas possibilidades para o silêncio do Filebo: 1) o silêncio como a própria posição hedonista; 2) o silêncio como covardia e imperícia intelectual. Diante destas duas possibilidades adentramos, inicialmente, na segunda interpretação:

Encerrados nessa caricatura, esses hedonistas de pacotilha - Filebo e Protarco - não merecem um segundo de trabalho, evidentemente... Se são obrigados a endossar a censura por celebrar o animal como modelo filosófico; se são obrigados a permanecer mudos diante da habilidade dialética e retorcida de seu interlocutor encarregado de seus mais belos adornos em cena; se servem apenas para fazer rir ou 
sorrir o espectador, o leitor do diálogo; se oscilam entre a ausência, identificável com a covardia, a recusa à luta, a imbecilidade crassa, a imperícia intelectual, como dedicar ainda uma parcela de tempo a examinar seu caso? (ONFRAY, 2008, p. 149, grifo nosso).

Não é raro uma posição hedonista ser comparada, ou ainda, rebaixada à animalidade. Se o hedonismo é vinculado com o prazer e a corporalidade, então, os hedonistas estariam mais próximos da animalidade do que do homem e sua vida para o pensamento ${ }^{1}$. Não obstante, além dessa animalidade que seria, em última instância, uma imperícia do pensamento, poderíamos encontrar em Filebo um dado psicológico que seria a sua pura covardia. Parece que Filebo não tem a musculatura intelectual necessária e nem a técnica para um bom cruzado, de tal modo que ele nem chega a subir no ringue para enfrentar Sócrates, o seu adversário intelectual platonizado.

Entretanto, ainda haveria outra possibilidade de interpretação desse silêncio de Filebo no texto de Onfray. Trata-se de compreender a recusa de Filebo de participar do diálogo como a própria posição hedonista. Neste pequeno trecho que vamos enfatizar abaixo, Onfray comenta sobre os dois personagens de Platão - Filebo e Protarco -, porém, o nosso foco agora é, sobretudo, o silêncio de Filebo. Lembremos que, para Onfray, a etimologia do nome Filebo é "aquele que gosta de jovens" e a etimologia do nome Protarco é "aquele que governa":

Filebo parte para ir atrás dos meninos? Nesse caso, merece a qualidade de hedonista ao preferir a ação jubilosa à conversa sobre o prazer... Protarco trava uma luta digna desse nome? De modo nenhum. Por mais que Sócrates desenvolva seus argumentos, encadeie suas digressões, use de astúcia em suas análises, lance poeira aos olhos classificando, distinguindo, definindo, opondo, ele executa uma performance de ator, desempenhando o papel do retor, do dialético, do filósofo que conquista a adesão com uma facilidade desconcertante. Com um ausente e um indigente, o hedonismo corre pouco risco. A refutação anunciada mais parece um acerto de contas. O Filebo mostra um Sócrates que mira uma bala entre os dois olhos de Protarco antes de, grande senhor, abrir mão de apertar o gatilho...(ONFRAY, 2008, p. 145).

Neste momento o mutismo de Filebo se transforma na própria prática hedonista, ou seja, Filebo recusa a fazer parte do diálogo, pois não quer a conversa sobre o prazer (logos), mas, sim, praticá-lo (práxis).

É possível pensar que entre a interpretação de que a mudez de Filebo seja uma covardia e a de que ela reflete uma posição hedonista exista um maior refinamento intelectual

\footnotetext{
${ }^{1}$ Como exemplo poderíamos lembrar o epicurismo greco-romano, em que Epicuro seria chamado de porco, haveria uma imperícia intelectual e física, posto que os porcos não conseguiriam erguer a cabeça para olhar para cima, não haveria a possibilidade de uma ascensão dialética.
} 
hermenêutico na compreensão do silêncio do personagem como a afirmativa pungente de sua posição. Se radicalizarmos esta posição de Filebo, ele se transforma num apropriado lutador de boxe e com um perigoso jab dogmático, posto que a força do prazer silencioso se impõe sobre a frágil construção dialógica. Dessa maneira, compreendendo o silêncio de Filebo, também, como uma possível posição dogmática é que passamos para a análise de Hans-Georg Gadamer.

\section{O FILEBO DE HANS-GEORG GADAMER}

Vamos nos aproximar da obra de Hans-Georg Gadamer da mesma forma que nos avizinhamos do texto de Michel Onfray. Assim sendo, trata-se, primeiro, de uma apreensão dos pressupostos e da finalidade do texto e, depois, uma análise de como o autor compreende o silêncio de Filebo. O nosso texto base é a obra A ideia do bem entre Platão e Aristóteles e, especificamente, o capítulo intitulado "A dialética do bem no Filebo".

Quando pensamos na interpretação que Gadamer faz de Platão é necessário citarmos a influência de Martin Heidegger no projeto gadameriano. Nas primeiras páginas d'A ideia do bem entre Platão e Aristóteles encontramos o seguinte reconhecimento ao filósofo autor de Ser e tempo:

\footnotetext{
Meu encontro com Heidegger àquela época foi decisivo para mim. Ele experimentara não apenas a tradição católica do aristotelismo, mas também o neokastismo, tendo fortalecido, na minuciosa arte conceptual de Husserl, a perseverança e a força intuitiva, predicados indispensáveis para se filosofar com Aristóteles. E vejam só: ali surgia um advogado de Aristóteles que, no tocante à naturalidade e ao frescor de sua escrita, em muito superava todos os aspectos tradicionais do aristotelismo, do tomismo e - por que não dizer - do hegelianismo. Até nossos dias, quase nada se fez conhecer sobre esse fato. Não obstante, sua eficácia pode-se manifestar no âmbito acadêmico do ensino, e meu próprio caminho viu-se marcado a partir de então. Quando, no ano de 1931, publiquei meu primeiro livro, Platos dialektisch Ethik, havia-se evidenciado para mim, pelos menos no campo da filosofia prática, a convergência entre as intenções de pensamento platônicas e as distinções conceptuais aristotélicas. (GADAMER, 2009, p. 3).
}

Com Heidegger, Gadamer tem diante de si um Aristóteles revigorado para o seu tempo, posto que seria possível compreender o filósofo grego fora do quadro escolástico, assim, ativando-o no seio de uma filosofia prática. Gadamer, por sua vez, compreende Platão fora do quadro metafísico, produzindo uma aristotelização de Platão. Coloca-o, além disso, na esfera de uma filosofia prática. Platão inserido dentro do ambiente da vida prática se torna 
novamente interessante, posto que o regime mental moderno é avesso a conceitos metafísicos como, por exemplo, a ideia de Bem.

Todavia, mesmo diante da influência de Heidegger, Gadamer não vai deixar de questioná-lo, isto é, de criar sua própria produção teórica que se direciona para lugares distantes do solo heideggeriano. Catherine Zuckert (1996), por exemplo, aponta que em contraste com Heidegger o estudo de Gadamer dos diálogos platônicos, em geral, e do Filebo, em particular, mostra que não há uma ruptura decisiva entre o homem que se preocupa com as questões práticas a sua volta e o homem que se preocupa com as questões teóricas das coisas em si. Com Gadamer encontramos uma imanentização do pensamento platônico.

Dessa maneira, "Gadamer insiste que o ponto principal dos diálogos socráticos é mostrar que o ser humano precisa saber o que é realmente e verdadeiramente Bom - para estar apto a satisfazer os seus desejos e preocupações do dia a dia" (ZUCKERT, 1996, p. 72, grifo nosso). Neste solo da vida cotidiana ainda emerge uma radicalidade interpretativa de Gadamer que é compreender que os conceitos metafísicos surgem diretamente das preocupações dramatizadas por Platão nos seus diálogos. O diálogo platônico, neste momento, não se torna tão somente um inquérito, ou ainda, um ringue entre lutadores-tese, mas, sobretudo, o diálogo é compreendido como uma forma de vida filosófica. Posto o diálogo como esta forma de vida, ou ainda, como a própria hermenêutica, podemos adentrar na leitura que Gadamer faz de Filebo. Nesta leitura temos, especialmente, o foco na recusa do diálogo, isto é, no silêncio de Filebo.

Na obra A ideia do bem entre Platão e Aristóteles a parte que mais nos interessa é quando Gadamer concentra sua análise na obra Filebo, no tópico "A dialética do bem no Filebo". Desse fragmento podemos compreender alguns pontos vitais para a nossa análise como, por exemplo: 1) a posição do silêncio dogmático do Filebo; 2) a abertura para o diálogo com Protarco; 3 ) e, por último, temos a condição para uma relação dialógica. É perpassando esses três elementos que caracterizamos o silêncio do Filebo.

Quando tomamos o primeiro ponto, o silêncio dogmático de Filebo, devemos nos lembrar da posição de Filebo que afirmaria o seguinte: "bom é o agrado, o prazer, o deleite e quanto for consoante com esse gênero" (PLATÃO, 2012, p. 25). A esse respeito Gadamer faz um comentário importante que remonta ao mutismo do personagem:

O princípio do prazer possui uma espécie de obviedade desmesurada e avassaladora, da mesma maneira que comanda o comportamento de todos os seres vivos. Parece uma contradição em si que esse princípio deva ser defendido em discurso e resposta; 
nesse sentido, é totalmente coerente que os representantes desse princípio se defendam exatamente contra o dom de esclarecimento por meio do discurso e da resposta. A impressão mais visível desse fato é vermos que Filebo, o herói que empresta seu nome ao diálogo, retrai-se por completo do diálogo. (GADAMER, 2009, p. 107).

Nesse momento, ainda, não estamos diante de uma caracterização de Gadamer do silêncio de Filebo como essencialmente dogmático. Assim, parece-nos que haveria uma obviedade - e por ser óbvio não é necessária a explicação - na posição hedonista, posto que todos buscariam o prazer. Todavia, Filebo não se abre ao diálogo, ele não ascende ao processo dialético, dessa maneira, reafirma a sua posição - agora de forma dogmática - e não participa ativamente do diálogo, porém, se mantém como uma forte presença corporal, pois sabemos o todo tempo que Filebo está na escuta da conversa. Gadamer, então, passa a configurar o silêncio de Filebo da seguinte maneira:

\begin{abstract}
É coerente o modo como Filebo não se contrapõe a essa exigência [o esclarecimento via diálogo] com argumentação lógica, mas, insistindo, de forma dogmática, na prioridade absoluta da hedoné: "assim penso, e assim sempre hei de pensar". Ele já se retrata, para não ter de aceitar alguma exigência incômoda que viesse a desagradar à sua "deusa", a Hedoné (encarnação do Prazer). [...] Em oposição à sacralização artificial da Hedoné por Filebo, Sócrates atém-se ao nome de culto. Ou seja, ele a reconhece como um membro do panteão de deuses do Olimpo. Dentro dessa questão, exprime-se a validade parcial e o caráter limitado da pretensão por hegemonia dessa potência mundial da hedoné. Apenas uma única vez, Filebo dignase a voltar a abrir a boca, e somente o faz para uma vez mais reforçar que não se podem impor limites à sede de prazer (e, como as palavras de Nietzsche: "pois todo prazer quer eternidade"). (GADAMER, 2009, p. 107-108).
\end{abstract}

Se com Michel Onfray a posição de transformar o silêncio em ouro e a fala em prata tem ainda o seu brilho, posto que seria negar a conversa sobre o prazer para praticá-lo; com Gadamer este silêncio é, sobretudo, uma posição dogmática, uma indisposição ao diálogo. Assim, o silêncio de ouro perde totalmente o seu encanto.

Daí é que encontramos a figura de Protarco que nos coloca diante do segundo ponto, a abertura para o diálogo, posto que ele "abandona a imaturidade de menor incapaz que possuía enquanto partidário de Filebo, evoluindo para a posição de interlocutor aberto de Sócrates" (GADAMER, 2009, p. 111). Protarco, dessa forma, está longe das características que Onfray lhe outorga como "beato", "tolo", ou ainda, "silencioso". Pensamos que para Gadamer, Protarco se configura como uma verdadeira potência dialógica, isto é, poderíamos até mesmo chamá-lo de uma potência democrática. Quando Protarco muda sua posição, do silêncio ao diálogo, é que se torna possível um total refinamento do que são os prazeres e uma vida boa. 
A posição socrática na conversa, por sua vez, é louvável, porque "ele [Sócrates] não faz uso de qualquer autoridade, preferindo deixar o interlocutor novamente livre, para assim encontrar o discernimento. Desta forma, Sócrates realmente consegue que seu interlocutor, por vontade própria, entre no movimento dialético" (GADAMER, 2009, p. 110).

Diante desses elementos nos colocamos em face das condições de possibilidade do diálogo. No entanto, salientemos que a precondição envolve tanto uma predisposição afetiva quanto uma predisposição intelectual. Se pensarmos em Protarco, ele muda tanto afetivamente - nele há uma humildade para iniciar o diálogo - quanto intelectualmente - a possibilidade de compreensão e uma nova articulação dos signos da linguagem. A respeito da linguagem, Gadamer (2009, p. 120) afirma que:

\footnotetext{
Ela [a fala] é a precondição de todo diálogo (e de todo "diálogo" com forma literária) e, no final, do pensamento que a tudo diferencia, dito de forma genérica. Nesse sentido, ela naturalmente também vale para a busca da vida justa, representada no Filebo. Mas não quer dizer que, por terem aprendido a falar (ou a escrever), os que buscam a vida justa já estejam no bom caminho dialético do entendimento genuíno sobre o Bem.
}

A capacidade da fala, então, seria uma precondição para o diálogo, seria a possibilidade para a hermenêutica. Todavia, não se trata tão somente de tê-la como uma ferramenta para que o homem esteja incluso no caminho da vida justa, ou ainda, do entendimento genuíno do Bem. Para essa transição são indispensáveis outros elementos que constituem uma relação realmente dialógica. Trata-se de dois elementos: 1) uma abertura para o outro; 2) e uma procura da verdade.

O diálogo autêntico evoca necessariamente uma abertura para o outro, uma relação de reciprocidade. Portanto, não seria possível compreender o processo dialético como um ringue, como uma luta entre adversários. Gadamer (2009, p. 119) aponta que "o bom caminho do entendimento trilhado pelo diálogo no Filebo realmente deixa para trás - a esse respeito, Sócrates advertia no início - os artifícios erísticos de uma dialética ilusória”. Quando se deixa de lado a vontade de abater um adversário, quando se deixa de lado a vontade de se obter um determinado sucesso no debate, então, abre-se uma relação mútua para a procura da verdade. Estes dois elementos, abertura para o diálogo e procura conjunta da verdade, são o que constitui um autêntico diálogo. Nesse momento, voltamo-nos, então, para o entendimento de como a figura de Filebo é problemática, posto que ele recusa o diálogo, assim, Gadamer pode 
caracterizar facilmente o silêncio de Filebo como dogmático, já que Filebo não se abre à verdade do outro.

\section{CONCLUSÃO: A IMPOSSIBILIDADE DA VIDA FILOSÓFICA}

No decorrer desta reflexão sobre o silêncio de Filebo foram explicitadas algumas ponderações a respeito do mutismo de Filebo. Os dois filósofos analisados foram o francês Michel Onfray e o alemão Hans-Georg Gadamer. Com o filósofo francês, o silêncio de Filebo é compreendido como uma possível covardia, uma imperícia intelectual, ou ainda, como a marcação de uma posição hedonista. Com o filósofo alemão, o silêncio de Filebo é entendido como um silêncio dogmático, posto que Filebo não se abre para uma autêntica relação dialógica, ou ainda, para um modo de vida filosófico.

Quando pensamos na análise de Michel Onfray, haveria sobretudo um Platão boxeador criando um Filebo sem a musculatura necessária par uma boa luta. A posição hedonista não teria a menor chance, e sua derrota estaria posta mesmo antes de colocar os pés no ringue, pois Platão criaria personagens conceituais fracos para vencê-los com facilidade. Para Onfray caberia, então, seguir a linha de fuga ativa na produção de um hedonismo mais potente a ponto de combater a história dos vencedores. Essa parece ser a própria função de uma contrahistória da filosofia.

Mas, quando pensamos na análise de Hans-Georg Gadamer, Filebo parece ser uma minoração da potencialidade hermenêutica. Filebo no seu dogmatismo, "assim penso e assim hei de pensar", não mostra a menor abertura para o autêntico processo dialético em que se configuram a abertura sincera para o outro e a procura conjunta da verdade. Em ambos os autores - Onfray e Gadamer - o silêncio de Filebo, mesmo que tratado de forma tangencial, é para nós uma problematização forte.

Desse modo, compreendendo a problemática do silêncio do Filebo é que deveríamos radicalizar e dizer que Filebo está em todas as linhas do diálogo platônico. Filebo é a presença ausente que causa um verdadeiro curto-circuito no diálogo. Filebo é a força disruptiva que o próprio Platão injeta no seu diálogo. Agora caberia perguntar não mais sobre o silêncio de Filebo, mas, sim, sobre o silêncio de Platão que não convoca seus personagens a tirarem Filebo da sua posição e adentrar na conversa, no diálogo, na dialética e positivar o processo da hermenêutica. Parece-nos que esse silêncio de Platão, no Filebo, tem uma dupla 
significação: não é possível obrigar o outro a entrar no diálogo - isto seria a violência - e, por consequência, há uma impossibilidade de uma universalidade da vida filosófica.

\section{REFERÊNCIAS}

GADAMER, Hans-Georg. A ideia do bem entre Platão e Aristóteles. Tradução Tito Romão. São Paulo: Editora Martins Fontes, 2009.

LAWN, Chris; KEANE, Niall. The Gadamer dictionary. Nova York: Continuum Group, 2011.

ONFRAY, Michel. Contra-história da filosofia: a sabedoria dos antigos. Tradução Monica Stahel. São Paulo: Martins Fontes, 2008.

PLATÃO. Filebo. Tradução Fernando Muniz. Rio de Janeiro: Ed. PUC-Rio; São Paulo: Loyola, 2012.

ZUCKERT, Catherine. Postmodern Plato's: Nietzsche, Heidegger, Gadamer, Strauss, Derrida. Chicago: The University of Chicago, 1996. 